\title{
Submarine canyons of north-western Sicily (Southern Tyrrhenian Sea): Variability in morphology, sedimentary processes and evolution on a tectonically active margin
}

\author{
Claudio Lo Iacono ${ }^{\mathrm{a}, \mathrm{b}, *}$, Attilio Sulli $^{\mathrm{c}}$, Mauro Agate ${ }^{\mathrm{c}}$ \\ a Marine Geosciences, National Oceanography Centre, European Way, Southampton SO14 3ZH, United Kingdom \\ ${ }^{\mathrm{b}}$ Instituto de Ciencias del Mar-BCSI, Consejo Superior de Investigaciones Científicas, Paseo Marítimo de la Barceloneta 37-49, 08003 Barcelona, Spain \\ ${ }^{\mathrm{c}}$ Dipartimento di Scienze della Terra e del Mare dell'Università di Palermo, Via Archirafi 22, 90123 Palermo, Italy
}

\section{A R T I C L E I N F O}

\section{Available online 1 July 2013}

Keywords:

Submarine canyons

Tectonics

Landslides

Swath-bathymetry

Seismic data

Sicily

Southern Tyrrhenian Sea

\begin{abstract}
A B S T R A C T
Swath-bathymetry, mono-channel and multi-channel seismic reflection records acquired during the last two decades on the northern Sicilian margin have unveiled a dense network of submarine canyons within the depth range of $80-2100 \mathrm{~m}$. The canyons display a relevant variability in their geometry, morphology and sedimentary processes. The margin shows a young, tectonically active shelf to slope setting, linking the Sicilian-Maghrebian Thrust Belt to the Tyrrhenian oceanic realm, developed during the Neogene-Quaternary time span. The aim of this study is to highlight the main governing factors that contributed to the evolution and differentiation of the northern Sicilian canyons, mainly focusing on the Gulf of Palermo and on the Gulf of Castellammare. Tectonic control is more evident in the canyons of the Gulf of Palermo, with submarine landslides retrograding on a steep slope and mainly controlling their evolution. Otherwise, canyons, tributaries and gullies mapped in the Gulf of Castellammare developed on a less steep substrate and display sinuous to meandering paths, with a relevant role of coastal/shelf sedimentary inputs and downslope turbidity processes in their formation. Results suggest that, despite the geographically close proximity of the two study areas, the different structural settings of the Castellammare and Palermo Basins are mainly responsible for canyon variability. Data indicate likely ongoing uplift and tilting movements along the Sicilian margin, influencing the development of the studied canyons, which have probably been more active during the Quaternary glacial maxima than they are in the present day.
\end{abstract}

(c) 2013 Elsevier Ltd. All rights reserved.

\section{Introduction}

Submarine canyons are widespread complex features along continental margins and are pathways for sediment transport to the deep basins (Piper and Savoye, 1993; Wynn et al., 2007; Palanques et al., 2012), They play a key role in hydrography, biogeochemistry and carbon cycle dynamics (Epping et al., 2002; Canals et al., 2006; Huvenne et al., 2011). Despite their importance, the processes of start-up, evolution and maintenance of submarine canyons remain poorly understood. Based on a wide range of canyon dimensions and morphologies observed in different geologic settings, the sedimentary processes responsible for shaping submarine canyons may be summarized in terms of top-down and bottom-up processes (Shepard, 1981; Twichell and Roberts, 1982;

\footnotetext{
* Corresponding author at: Marine Geosciences, National Oceanography Centre, European Way, Southampton SO14 3ZH, United Kingdom. Tel.: +44 2380596576.

E-mail addresses: cllo@noc.ac.uk, loiacono@icm.csic.es (C. Lo Iacono).
}

Piper and Savoye, 1993). The top-down processes mainly refer to turbidity and hyperpycnal flows occurring along the shelf margin which generate axial incision down to the slope, in alternating erosive and depositional dynamics (Baztan et al., 2005). At a global scale, top-down processes generally occur in moderate to high sediment-supply margins, alimented by coastal and fluvial sedimentary inputs, and are more frequent and active during the glacial phases (Canals et al., 2000; Baztan et al., 2005; Harris and Whiteway, 2011). Bottom-up processes are governed by the development of stacked mass-movements retrograding through the lower slope to the shelf margin and are more commonly observed in sediment-undersupplied margins, in tectonically active high-gradient bedrock slopes (Lo Iacono et al., 2011; Biscara et al., 2012; Micallef et al., 2012). Commonly, both of these mechanisms contribute to canyon shaping and development, with top-down turbidity processes producing axial incision from the shelf, and bottom-up retrograding landslides widening the canyons and producing downslope debris flows (Pratson and Coakley, 1996; Lo Iacono et al., 2011). Moreover, active tectonics play a relevant role 
in controlling the evolution and the morphology of submarine canyons, above all along continental margins affected by tilting and vertical movements (Mountjoy et al., 2009; Ratzov et al., 2012).

Offshore north-western Sicily (southern Tyrrhenian Sea) swath-bathymetry and high resolution seismic data have unveiled a dense network of submarine canyons within the depth range of 80-2100 m, across a wide range of morphologies and stratigraphic settings. The main aims of this work are: (1) to describe the morphologies of submarine canyons mapped in the Gulfs of Palermo and Castellammare, (2) to identify the main sedimentary and geological processes which contributed to canyon formation, and (3) to infer on the main sedimentary processes which can have contributed in maintaining some of the submarine canyons during the last glacial-interglacial phase.

\section{Geological and oceanographic settings}

\subsection{Geological setting}

The northern Sicily continental margin, in the southern Tyrrhenian Sea, extends from the north Sicily coastal belt to the
Marsili bathyal plain (Fig. 1a). The margin is located in the transitional area between the Sicilian-Maghrebian chain to the south and the Tyrrhenian back-arc basin to the north (Kastens et al., 1988; Scarascia et al., 1994). This region originated as a consequence of a complex interaction of compressional events, crustal thinning and strike-slip faulting (Pepe et al., 2005). Tectonic activity started in the early-middle Miocene with the thrusting of the Kabilian-Calabrian units and deformation of the most internal units of the Sicilian-Maghrebian chain (Catalano et al., 1985; Pepe et al., 2005), while the opening of the Tyrrhenian Sea led to the subsidence of the margin since the Late Tortonian (Bacini Sedimentari, 1980; Fabbri et al., 1981). Late Miocene-early Pliocene high-angle reverse faults, involving mainly deep seated carbonate units, produced structural highs (Avellone et al., 2010), representing the northern shoulders of intraslope basins (e.g. the Palermo Basin and the Castellammare Basin), termed "periTyrrhenian basins" by Selli (1970). These basins were eventually filled with Upper Neogene to Quaternary evaporitic, hemipelagic, siliciclastic and volcaniclastic deposits, up to $1200 \mathrm{~m}$ thick (Sedimentari, 1980). Normal faults affected the inner side of the margin during the middle (?)-late Pliocene, partly dissecting the back- and fore-limbs of the structural high, and generating major
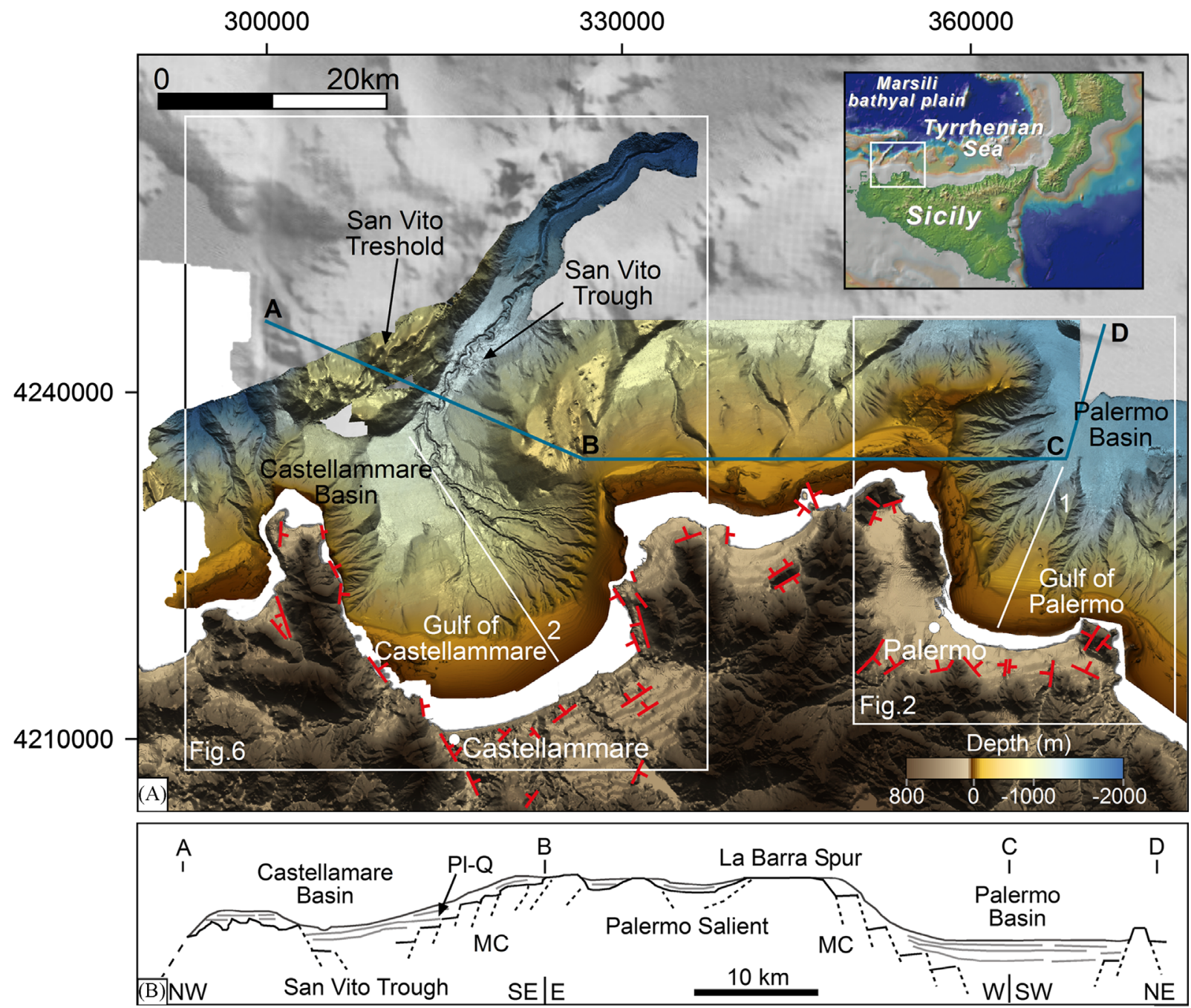

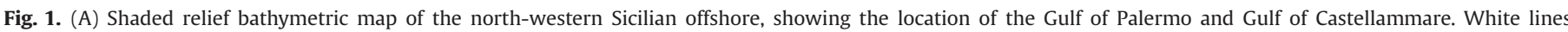

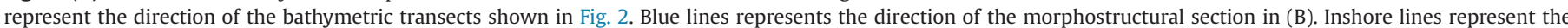

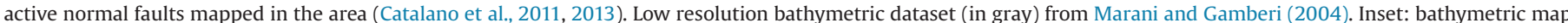

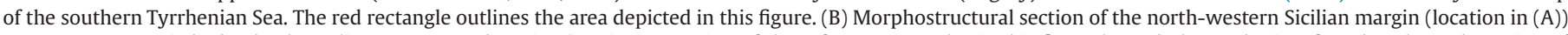

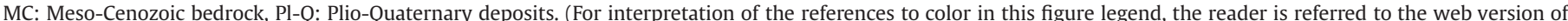
this article.) 
extensional basins (e.g. Cefalù Basin) with a prevailing syn-tectonic deposition (Pepe et al., 2003). E-W, NW-SE and NE-SW-trending normal faults with a local strike-slip component, exerted control on the morphology of the present day shelf and coastal areas during the Pleistocene. Folding of Upper Pliocene-Pleistocene basin infill (Agate et al., 1993) and positive flower structures (Del Ben and Guarneri, 2000) reveal the alternation of extensional/transtensional and compressional/transpressional activity until the recent time. The present-day resulting morphology is an alternation of morphostructural highs (San Vito threshold, Palermo Salient, La Barra Spur, and Solunto Seamount), and depressions (Castellammare Basin, San Vito through, and Palermo Basin) from west to east, and the occurrence of structural thresholds from the continental shelf to the bathyal plain (Fig. 1B).

The upper plate seismicity of the northern Sicilian margin is defined by compressional focal mechanisms to the west and extensional to strike-slip mechanisms to the east. Shallow $(<25 \mathrm{~km})$ seismic events of low to moderate magnitude (max Md 5.6 in September 2002) occur along an ENE-WSW trending belt located northward in agreement with a dominant NE-SW fault trend coupled with a NW-SE compressive offset direction (Agate et al., 2000; Giunta et al., 2009). The highest uplift rates during the last $125 \mathrm{ky}$ in northern Sicily were found on inner margin-terraces located along the eastern coast $(0.8-1.63 \mathrm{~mm} / \mathrm{y})$, where the Holocene rates are between $20 \%$ and $70 \%$ higher than those calculated for the Tyrrhenian stage (Ferranti et al., 2010). The vertical tectonic rates show a decrease from $\mathrm{E}$ to $\mathrm{W}$, with the relative movements of adjacent sectors highlighting the role of coseismic activity of main structural features during the Pleistocene (Sulli et al., 2012). Inshore and offshore geologic data on the north-eastern margin demonstrate that while the mainland sector is uplifting, the offshore area is presently subsiding, suggesting the activity of fault systems parallel to the coastline, causing differential vertical movements (subsidence vs. uplift) (Sulli et al., 2012). On the other hand, observations from the northwestern margin suggest a present-day stability, except for local vertical movements in the Castellammare area, where uplift rates reach $0.1-0.2 \mathrm{~mm} / \mathrm{y}$ (Mauz et al., 1997; Antonioli et al., 2006).

The present-day northern Sicily continental margin is composed of: (1) a narrow (up to $10 \mathrm{~km}$ ) and steep (up to $2.5^{\circ}$ ) continental shelf, with the edge between $-95 \mathrm{~m}$ and $-140 \mathrm{~m}$; (2) a steep (up to $14^{\circ}$ ) upper continental slope ranging in water depth from 150 to $1000 \mathrm{~m}$; (3) a flat intra-slope basin at a depth of $1500 \mathrm{~m}$; (4) a lower continental slope, wider and gentler than the upper slope; (5) a bathyal plain below $3000 \mathrm{~m}$ water depth. Along the shelf and the upper slope, the Quaternary succession consists of seawards-dipping, clastic and terrigenous deposits (Pepe et al., 2003; Agate et al., 2005). On the continental shelf, Pleistocene deposits are truncated by an erosional surface formed during the last glacio-eustatic oscillation. Prograding, sedimentary wedges of coastal deposits, formed during the Last Glacial Maximum (LGM, about $18 \mathrm{ka}$ ), are present along the shelf margin (Agate et al., 1998). The prograding wedges are absent where the heads of the canyons or failure scars have indented the outer shelf (Lo Iacono et al., 2011).

\subsection{Oceanographic setting}

The study area corresponds to a micro-tidal setting, with maximum tidal height of $0.2 \mathrm{~m}$ above sea level (a.s.l.) (Istituto Idrografico della Marina, 2002), mainly dominated by sporadic winter storms coming from the NW, NE and E sectors (Astraldi et al., 2002). High energy events have a low recurrence period, occurring during $3 \%$ of the year, with maximum wave heights of 4-5 $\mathrm{m}$ and periods of $6 \mathrm{~s}$ (Istituto Idrografico della Marina, 1982).
The surface salinity varies from $37.6 \%$ to $38.2 \%$ between winter and summer (Demirov and Pinardi, 2002). The surface currents follow an anticyclonic regime, flowing parallel to the coastline from west to east with maximum velocities of 0.9 knots (Istituto Idrografico della Marina, 1982). Significant seasonal variations, both in velocity and direction, have been sporadically observed due to the formation of one or two circulation cells in the Southern Tyrrhenian Sea (Istituto Idrografico della Marina, 1982).

\section{Materials and methods}

Swath-bathymetry Multi Beam (MB) data were acquired during three different oceanographic cruises in 2001, 2004 (CARG cruises) and 2009 (MaGIC cruise) (Fig. 1) (www.isprambiente.it; Chiocci and Ridente, 2011). The MB system of the 2001 cruise was a Reson SeaBat 8111, generating 105 beams at a frequency of $100 \mathrm{kHz}$, with an operational depth range of $35-800 \mathrm{~m}$. The MB system of the 2004 and 2009 cruises was a Reson SeaBat 8160, generating 126 beams at a frequency of $50 \mathrm{kHz}$, for an operational depth range of 30-3000 m. Post-processing of MB data was accomplished with the PDS-2000 system. Post-processing steps included the removal of erroneous beams, noise filtering, processing of navigation data and correction for sound velocity. Digital Terrain Models (DTM) were produced with a footprint resolution of $15 \mathrm{~m}$. Global Mapper and Golden Software Surfer 9 were used to obtain 3D maps of the bathymetric data, shaded relief maps, slope maps and bathymetric profiles.

High resolution single-channel seismic profiles from the Palermo upper slope were acquired during the 2004 CARG cruise using a multi-tip sparker array, with a base frequency of around $600 \mathrm{~Hz}$, at $12.5 \mathrm{~m}$ shot interval. The resulting signal penetration exceeded $400 \mathrm{~ms}$ two way time (TWT) and the vertical resolution reached $2.5 \mathrm{~m}$ at the seafloor. The seismic lines were depth converted adopting an average velocity of $1700 \mathrm{~m} / \mathrm{s}$ for the PlioQuaternary sedimentary units. This velocity was derived from lithostratigraphy and sonic log data collected in wells from the southern and western Sicilian offshore (Catalano et al., 2000). Multichannel seismic records of the Palermo Basin named "Zona G" (acquisition sponsored by the Department of Industry of the Italian Government) were recorded in 1982 employing an AirGun array (capacity 2000 in. $^{3}$ ) with a $2400 \mathrm{~m}$ long streamer equipped with 96 groups, 15 geophones per group, group interval of $25 \mathrm{~m}$ and an active section length of $50 \mathrm{~m}$ (unmig.sviluppoeconomico.gov.it/ videpi/).

Seismic signals were received for $7 \mathrm{~s}$ TWT at a $2 \mathrm{~ms}$ sample period. Seismic records DEST4678 and DEST4679 were acquired during the "Sicily 96" oceanographic cruise (a joint research project between the Consiglio Nazionale delle Ricerche and the University of Palermo) employing an AirGun array (capacity $210 \mathrm{in}^{3}$ ) with a six-channel streamer, group interval of $25 \mathrm{~m}$, analog low pass $(300 \mathrm{~Hz})$ and notch $(50 \mathrm{~Hz})$ filters. Seismic signals were received for $2-7.5 \mathrm{~s}$ TWT at a $1 \mathrm{~ms}$ sample period. The seismic lines were interpreted with the software Geo-Suite using seismostratigraphy, seismic facies analysis and structural analysis methods and tools.

\section{Results}

Throughout the study area, we describe two canyon systems with different morphologies and sizes: the canyons of the Gulf of Palermo and the canyons of the Gulf of Castellammare (Fig. 1A). The two gulfs are bounded by promontories, made up of deformed Meso-Cenozoic sedimentary rocks (Agate et al., 1993) and by a central coastal plain, where the Meso-Cenozoic bedrock is 
buried, unconformably overlain by the Quaternary deposits. Both study areas are characterized by a variable extension of the continental shelf, different gradients of the continental slope and different river networks discharging sediments in the shelf.

Bathymetric transects from the Palermo and Castellammare Gulfs outline a difference in the extension and morphology of the shelf-upper slope systems (Fig. 2). Across the Palermo margin, an abrupt change of slope at a depth of $400 \mathrm{~m}$ separates a $4^{\circ}$ steep shallow sector from an up to $14^{\circ}$ steep slope to a depth of $1300 \mathrm{~m}$,
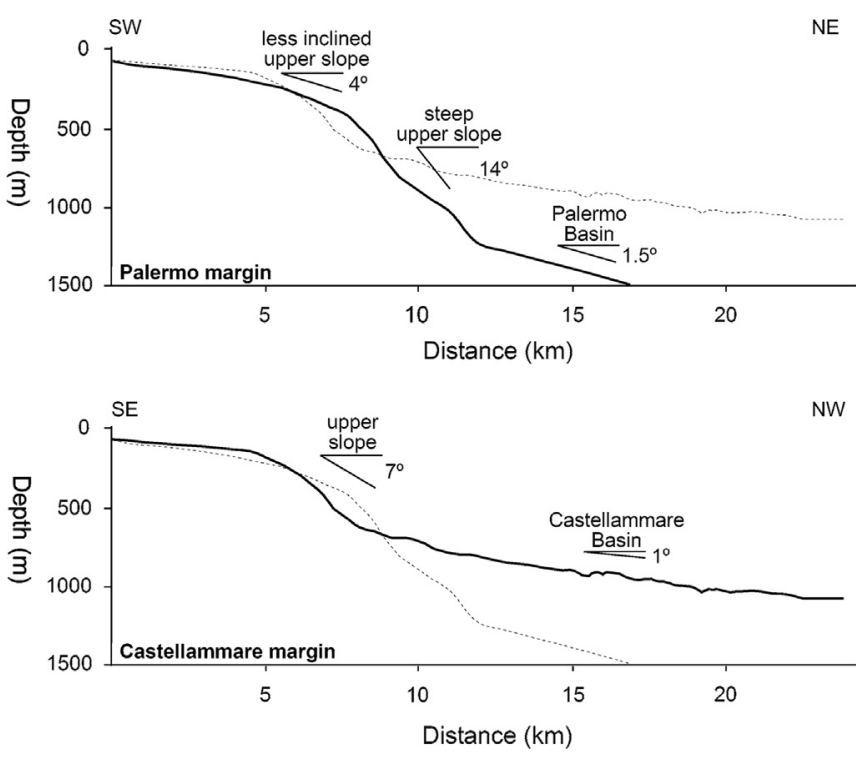

Fig. 2. Bathymetric transects across the Palermo and Castellammare margins Direction of transects is illustrated in Fig. 1A. Thin dotted lines correspond to the transects of the compared margin, in order to better highlight the differences in geometry and extension of the two study areas. where the $1.5^{\circ}$ sloping Palermo intra-slope basin starts (Fig. 2). The Castellammare margin displays a wide profile, with a marked shelf margin at the depth of $120-140 \mathrm{~m}$, a $6-7^{\circ}$ steep concave-up slope to a depth of $700 \mathrm{~m}$, decreasing to a $1^{\circ}$ gentle slope at a the depth of $1000 \mathrm{~m}$ (Fig. 2).

\subsection{Gulf of Palermo}

\subsubsection{Geomorphology}

Five main submarine canyons have been observed along the upper slope of the Palermo Basin (Lo Iacono et al., 2011); Fig. 3). Canyons are, from the east to the west: Eleuterio Canyon, Oreto Canyon, Arenella Canyon, Addaura Canyon and Mondello Canyon (Fig. 3). All the canyons indent the shelf, except for the Mondello Canyon, and show a straight path, connecting to the subhorizontal Palermo intraslope Basin (1500 m depth). Canyons range in depth from $112 \mathrm{~m}$ to $1388 \mathrm{~m}$ and $4.4-12.4 \mathrm{~km}$ in length. Average downslope gradients range from $6^{\circ}$ to $13^{\circ}$, with the steepest canyons along the north-western sector. All the canyons display an incised thalweg along the proximal reach, which flattens from a depth of $250 \mathrm{~m}$. The main morphometric parameters of the Palermo canyons are summarized in Table 1 . The maximum axis gradient, up to $13^{\circ}$, has been mapped in the Mondello Canyon, the westernmost of the Palermo canyons, which is slope confined and with the headscarp consisting of irregular shaped, coalescent scars at a depth between 300 and $400 \mathrm{~m}$ (Fig. 3). Southwards, the Addaura and Arenella Canyons display their headscarps made up of coalescent scars breaching the shelf edge (Fig. 3).

The Oreto Canyon displays a slightly sinuous shallow reach followed in the distal branch by a straight path. Its width increases steadily downslope up to $2000 \mathrm{~m}$ (Fig. 3). The Oreto Canyon has a small, elongated shelf-indenting headscarp, different from the amphitheater shaped headscarps of the other canyons. The Eleuterio Canyon, located in the easternmost sector of the Palermo

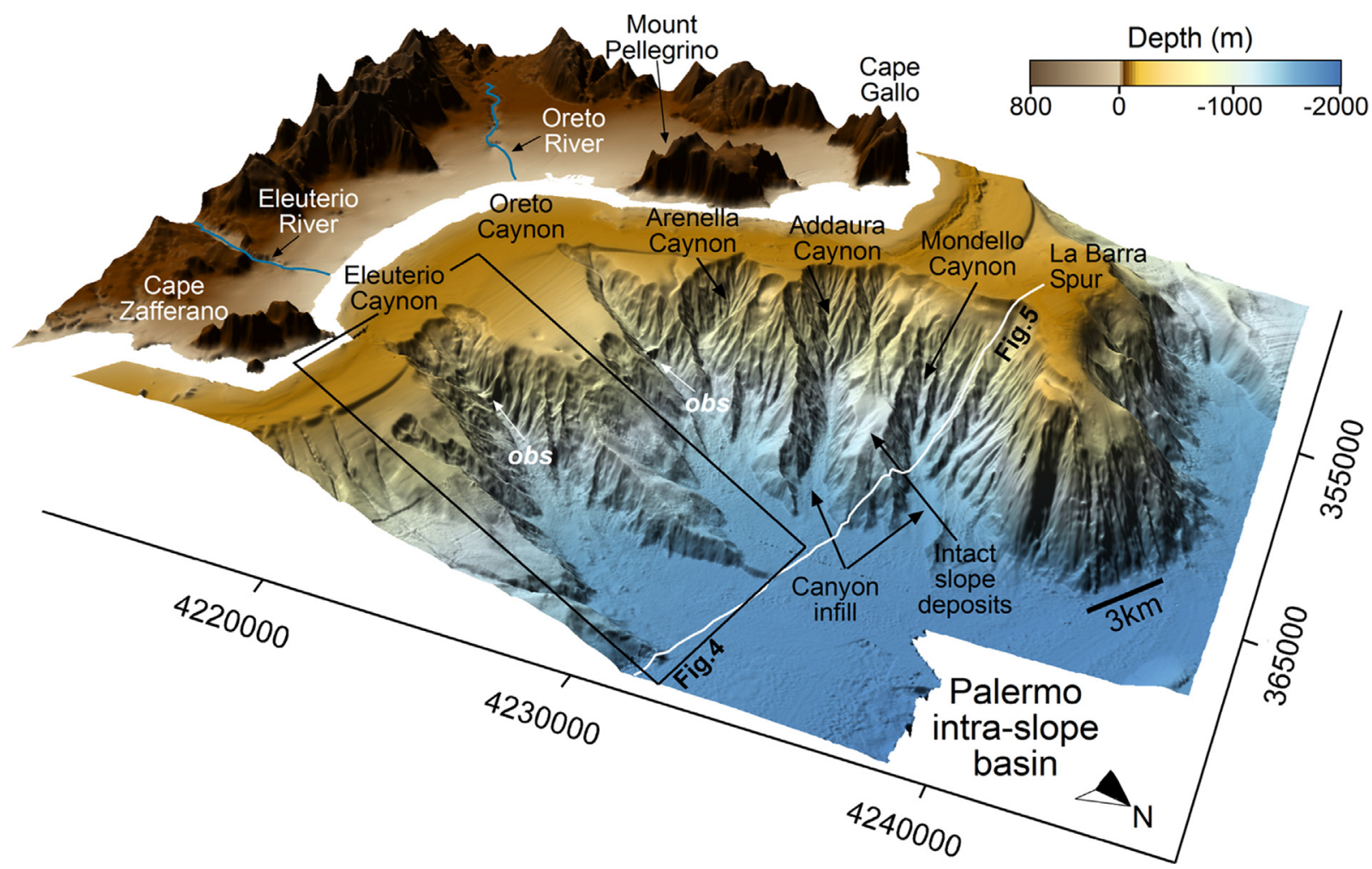

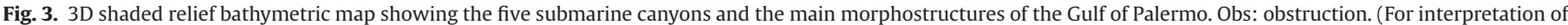
the references to color in this figure legend, the reader is referred to the web version of this article.) 
Table 1

Main morphometric values of the most prominent canyons in the north-western Sicily.

\begin{tabular}{|c|c|c|c|c|c|c|}
\hline \multirow[t]{2}{*}{ Main morphometric values } & \multicolumn{4}{|c|}{ Gulf of Palermo } & \multicolumn{2}{|c|}{ Gulf of Castellammare } \\
\hline & Mondello & Addaura & Oreto & Eleuterio & Castellammare & Tributary $\mathrm{C}$ \\
\hline Depth range $(\mathrm{m})$ & $356-1388$ & $123-1329$ & $120-1330$ & $120-1380$ & $116-2141$ & 135-1094 \\
\hline Difference in water depth (m) & 1032 & 1206 & 1210 & 1260 & 2025 & 959 \\
\hline Total length $(\mathrm{km})$ & 7.6 & 9.1 & 13.2 & 13.3 & 69 & 22.5 \\
\hline Straight length $(\mathrm{km})$ & 7.3 & 8.6 & 13.1 & 12.8 & 51.3 & 19.6 \\
\hline Average slope gradient (deg) & 7.7 & 7.5 & 5.2 & 5.4 & 1.8 & 2.4 \\
\hline Sinuosity & 1.04 & 1.05 & 1.01 & 1.03 & 1.19 & 1.15 \\
\hline Max right flank height (m) & 267 & 322 & 293 & 497 & 195 & 108 \\
\hline Max left flank height (m) & 205 & 322 & 341 & 464 & 184 & 71 \\
\hline Right flank gradient range (deg) & $15-25$ & $18-22$ & $15-18$ & $10-12$ & $8.6-23.3$ & $7.6-15.9$ \\
\hline Left flank gradient range (deg) & 20 & $14-23$ & $17-18$ & $16-18$ & $3.4-25.0$ & $5.2-14.3$ \\
\hline Maximum width $(\mathrm{m})$ & 2228 & 3510 & 2157 & 4490 & 1121 & 742 \\
\hline \multirow{2}{*}{$\begin{array}{l}\text { Range of height/width ratio and its downcanyon } \\
\text { variation }\end{array}$} & $0.06-0.16$ & $0.11-0.15$ & $0.09-0.17$ & $0.02-0.13$ & $0.03-0.18$ & $0.04-0.15$ \\
\hline & Irregular & Irregular & Irregular & Decreasing & Irregular & Irregular \\
\hline Distance of the headscarp from the coast (km) & 6.78 & 3.60 & 3.20 & 1.23 & 1.96 & 6.41 \\
\hline
\end{tabular}
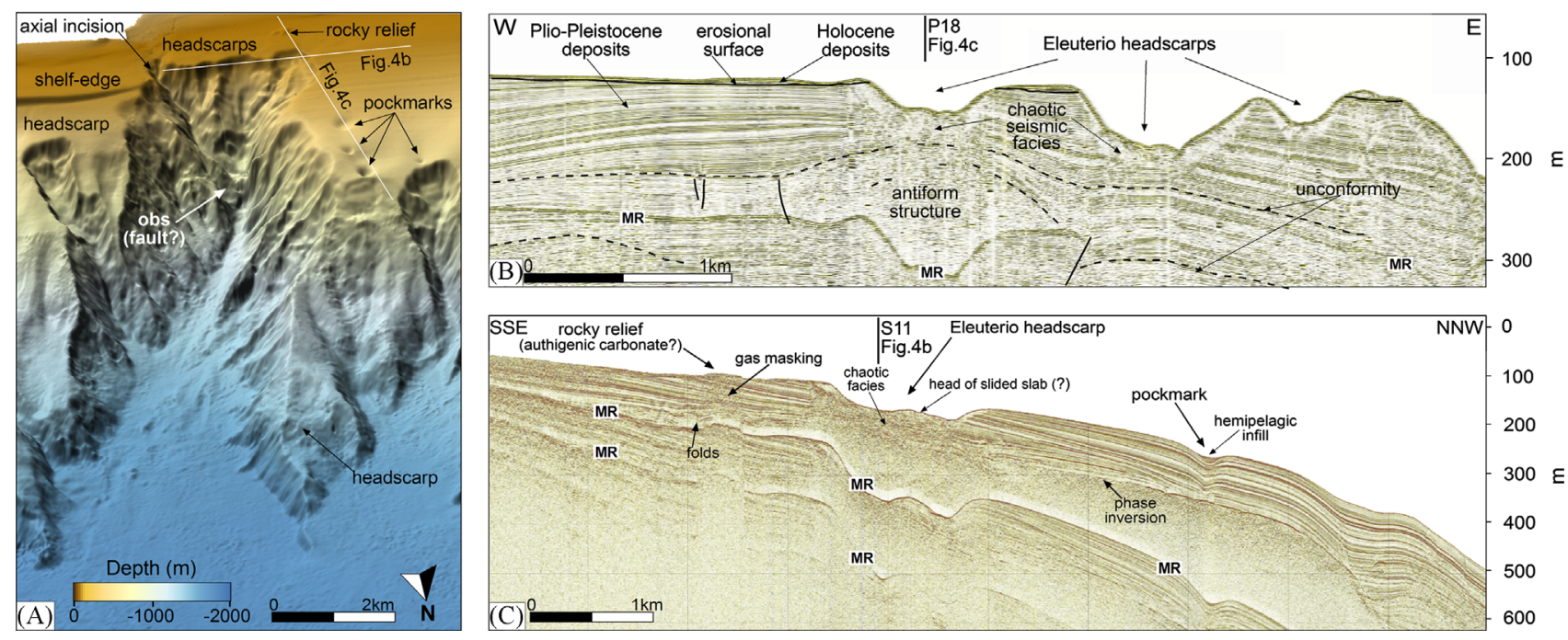

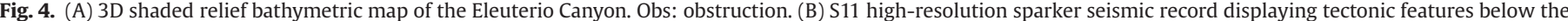

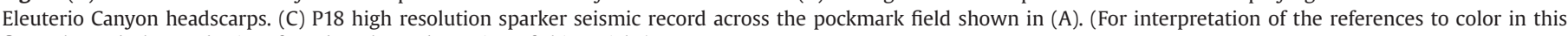
figure legend, the reader is referred to the web version of this article.)

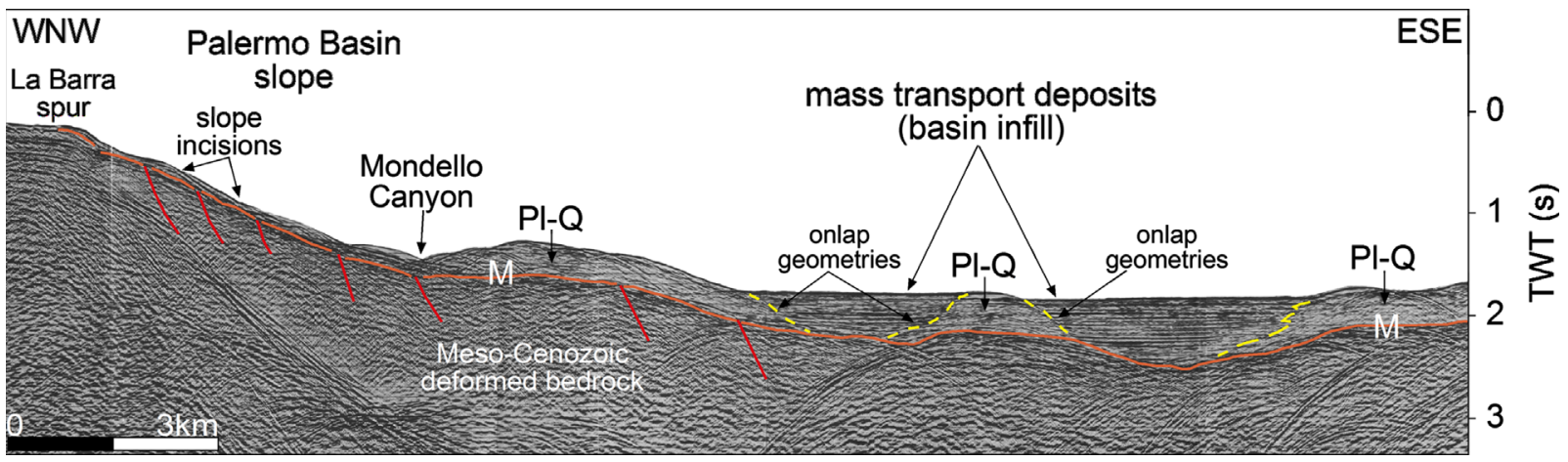

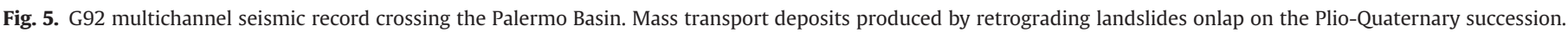
(For interpretation of the references to color in this figure legend, the reader is referred to the web version of this article.)

Gulf, is the largest erosive feature of the Palermo Basin, up to $4500 \mathrm{~m}$ wide and about $12 \mathrm{~km}$ long (Figs. 3 and 4). Its upper sector consists of five main crescent shape coalescent escarpments, from 500 to $1500 \mathrm{~m}$ wide. The head of the Eleuterio canyon is located in an area where recent tectonic antiform structures affect the upper portion of the Quaternary succession (Fig. 4A and B). The observed tectonic feature is aligned southwards with a rocky high in the shelf, probably consisting of authigenic carbonate deposits, and northwards with three pockmarks, 100 to $204 \mathrm{~m}$ wide and $15 \mathrm{~m}$ deep on average, along the Eleuterio left flank edge (Fig. 4C). Both the Oreto and the Eleuterio Canyons display a $20 \mathrm{~m}$ high obstruction at the same depth of $600 \mathrm{~m}$ ("obs" in Fig. 3), probably consisting of a tectonic feature. This lineament acts as a dam for downslope sediment transport processes and marks a change between a $\mathrm{V}$ transversal canyon profile upslope to a $\mathrm{U}$ transversal canyon profile downslope (Fig. 3). 


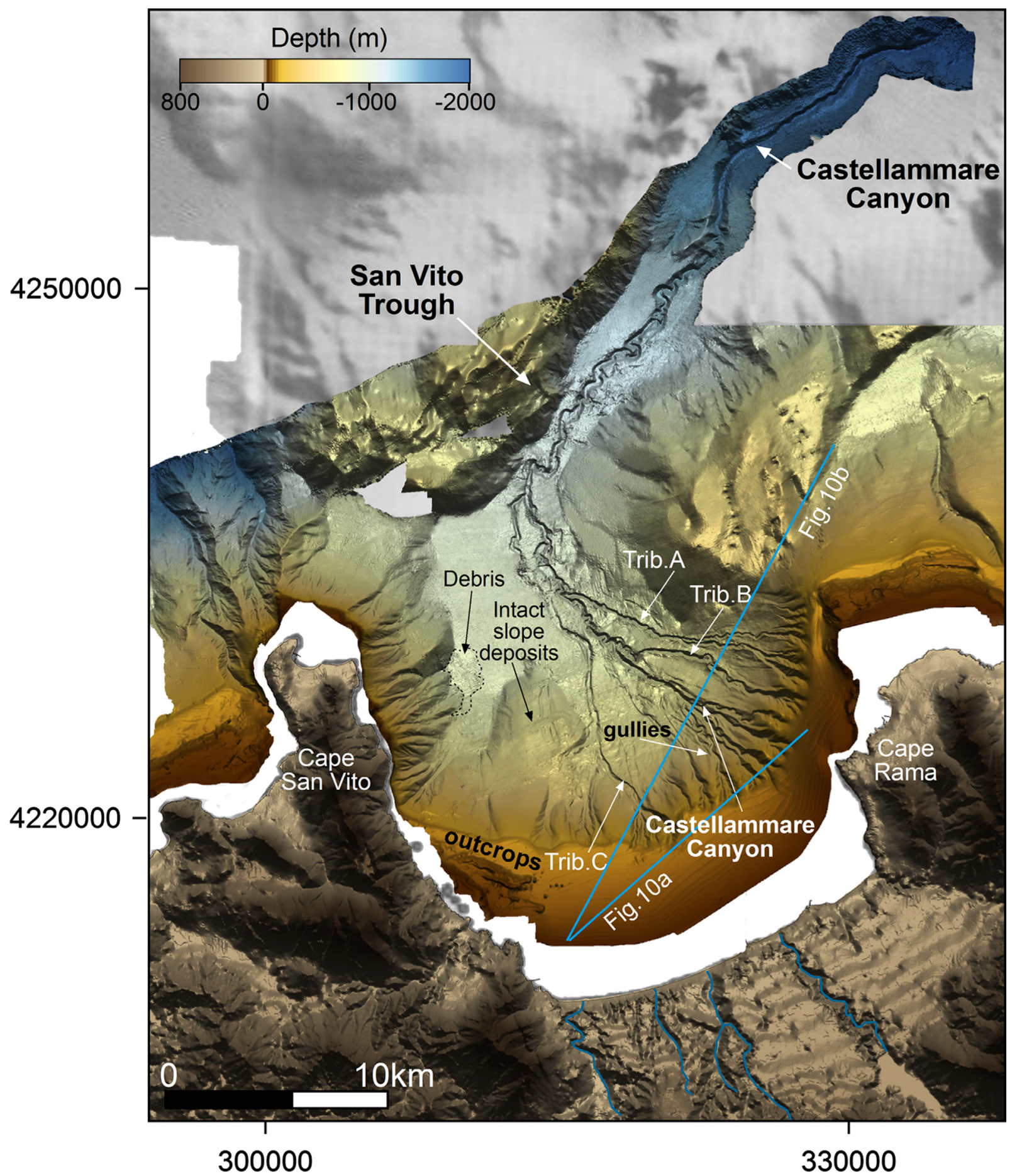

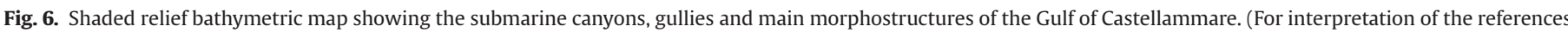
to color in this figure legend, the reader is referred to the web version of this article.)

\subsubsection{Seismostratigraphy}

A widespread high-amplitude and laterally continuous prominent reflector in the Palermo Basin, represents the top of the bedrock above which the Plio-Quaternary succession developed. This reflector is considered as a seismic marker correlated with the Messinian horizon (Fig. 5), below which low frequency horizons with variable amplitude are interpreted here as the MesoCenozoic carbonate and terrigenuous stratigraphic units outcropping on land. The Messinian horizon is unconformably overlain by a Plio-Quaternary clastic succession, several hundred meters thick, that extends from the coast to the Palermo intraslope basin
(Fig. 5). Along the shelf margin and the steep upper slope the Plio-Quaternary deposits are deeply scoured by landslide headscarps and by the Palermo submarine canyons (Fig. 3). Seismic records of the basin reveal the presence of sub-horizontal infilling deposits, up to $0.7 \mathrm{~s}$ thick, onlapping the Plio-Quaternary succession (Fig. 5). Along the continental shelf an extensive erosional surface truncates the seaward dipping Plio-Pleistocene reflectors (Fig. 4B). This surface has been recognized as having formed during the last sea level fall (post MIS 5e; Pepe et al., 2003; Caruso et al., 2011) when the shelf was exposed to subaerial processes and reworked during its following rise. 


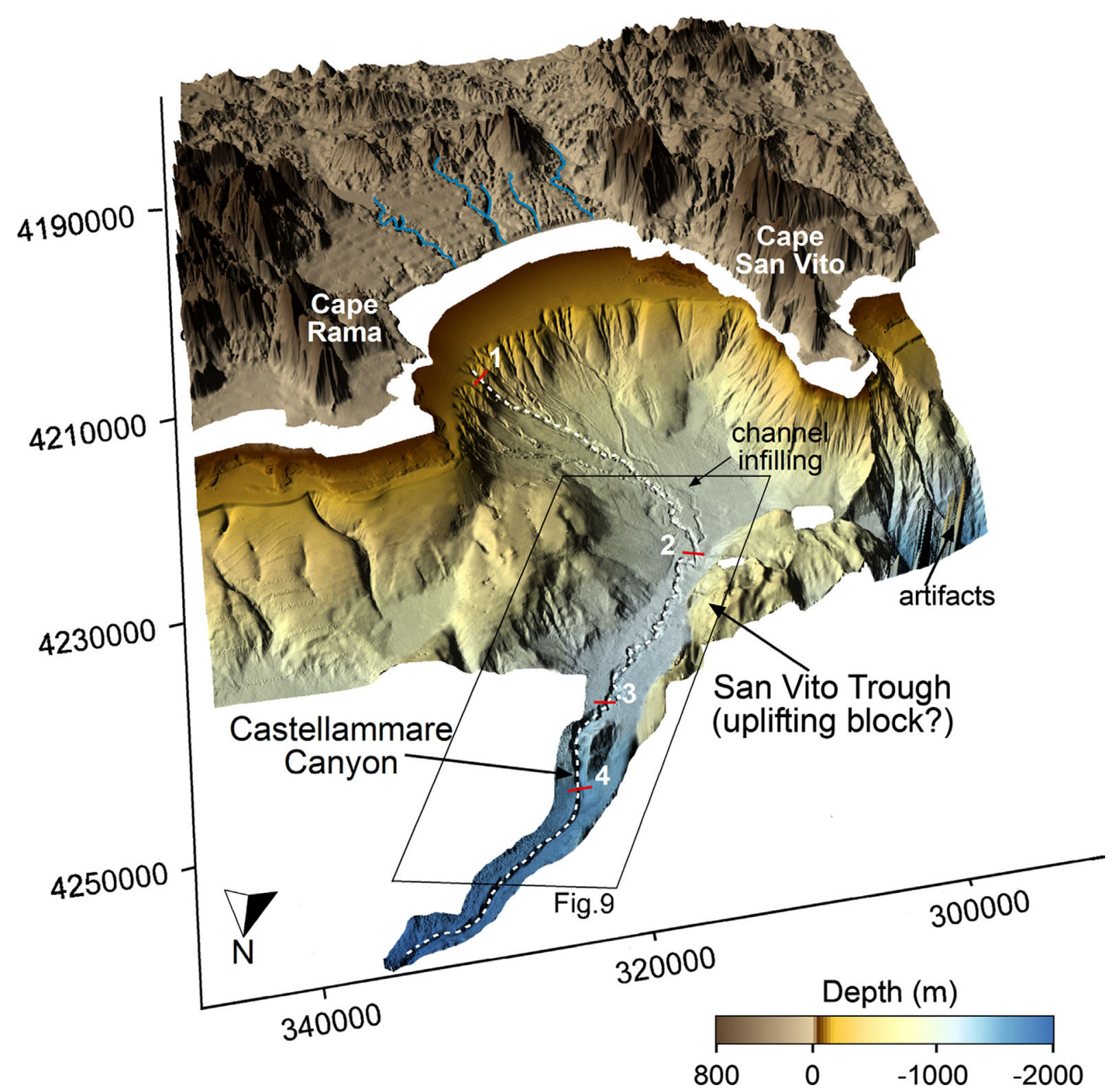

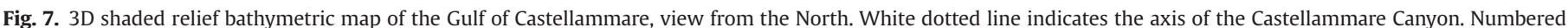

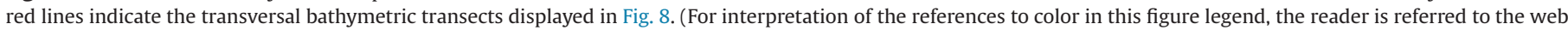
version of this article.)

\subsection{Gulf of Castellammare}

\subsubsection{Geomorphology}

4.2.1.1. Upper slope-Castellammare Basin (150 m-1100m).

The submarine canyons of the Gulf of Castellammare are clustered in the south-eastern sector of the slope, which displays maximum slope gradients of $7^{\circ}$. In this region, a number of narrow canyons and less incised gullies breach the shelf margin and extend landward in small and narrowing headscarps (Fig. 6). The Castellammare Canyon is the longest submarine canyon incising the NW Sicily margin (Fig. 6), originating $2 \mathrm{~km}$ off Cape Rama along the shelf margin and displaying a wide clockwise curve for a length of $70 \mathrm{~km}$ and maximum depths of $2200 \mathrm{~m}$. Its extension in to the deep basin has not been entirely mapped so far. Its course appears to be heavily influenced by the major morpho-structural features of the margin. Even though the common name of this canyon is "San Vito Canyon" we refer to it here as the Castellammare Canyon, because it crosses the entire Gulf of Castellammare and starts to develop far from the San Vito Peninsula. The main morphometric parameters of the Castellammare canyons are summarized in the Table 1.

The first reach of the Castellammare Canyon, from the shelfedge to the depth of $1100 \mathrm{~m}$, scours the upper slope with a straight to sinuous concave-up NNW-SSE course characterized by a number of close meanders (SI: 1.04), a V-shaped cross section profile and flanks up to $50 \mathrm{~m}$ high. A dense network of sinuous to meandering gullies along the southern side of the canyon displays a "birdfoot" shape and cuts the shelf margin with up to $800 \mathrm{~m}$ wide elongated heads (Fig. 6). Three tributaries aliment the Castellammare Canyon, two of them from the northern flank (tributaries A and $B$ ) and one from the southern flank (tributary C) (Fig. 6). The tributaries A and B display similar sizes, shapes and morphologic characteristics. Both of them show up to $100 \mathrm{~m}$ deep and $1000 \mathrm{~m}$ wide narrow heads along the shelf margin. Both the tributaries have a meandering to sinuous path (SI around 1.2) and a V-shaped cross section. Flanks are up to $40 \mathrm{~m}$ high and there 

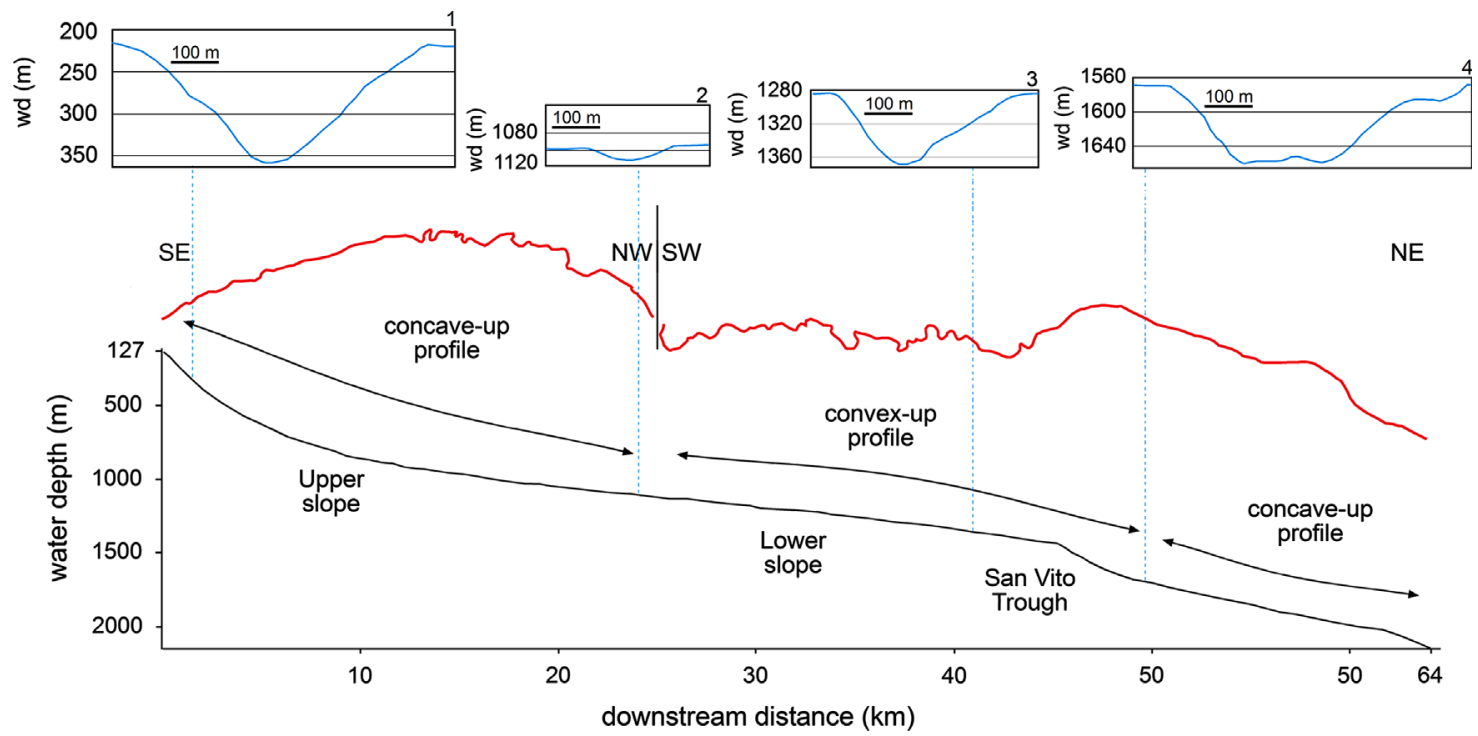

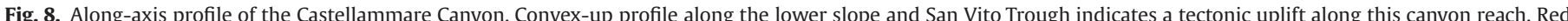

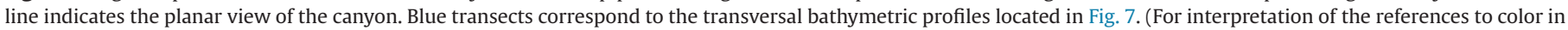
this figure legend, the reader is referred to the web version of this article.)
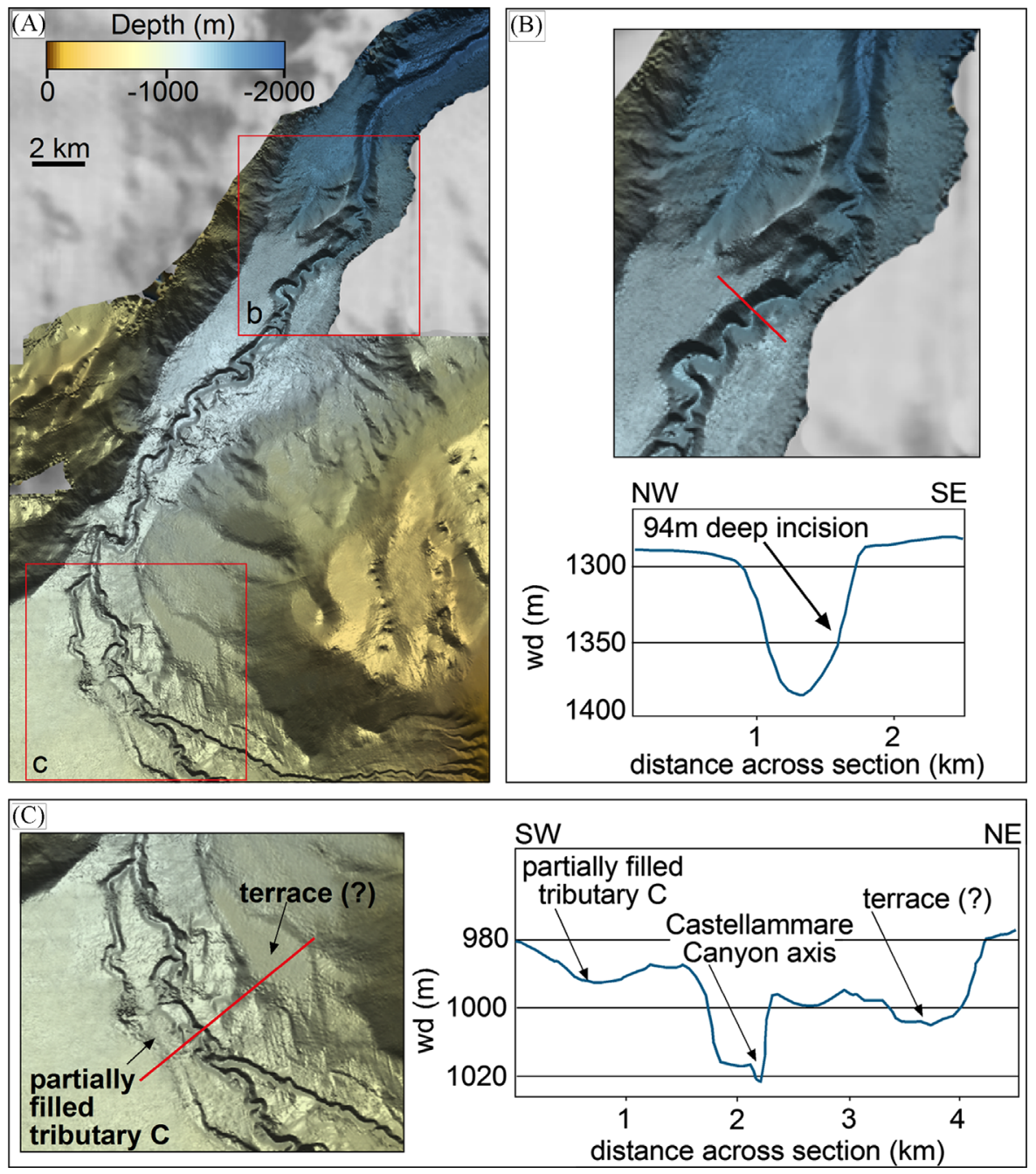

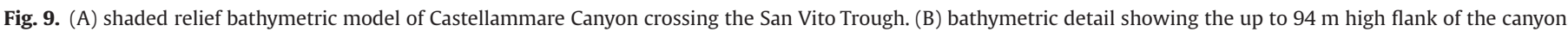

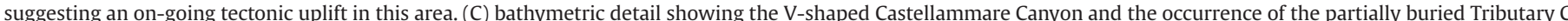

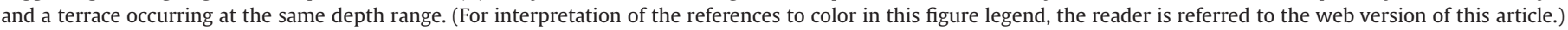



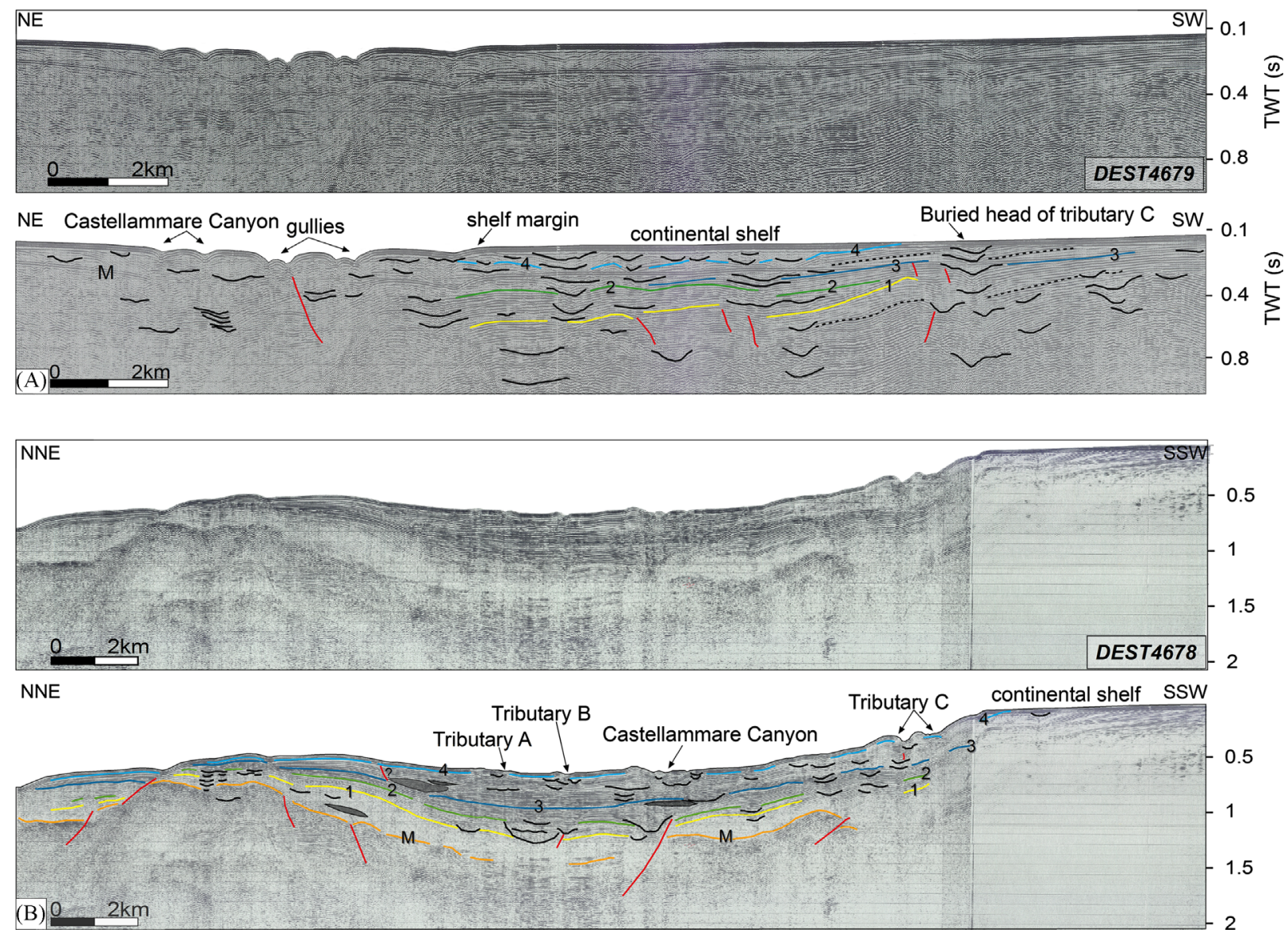

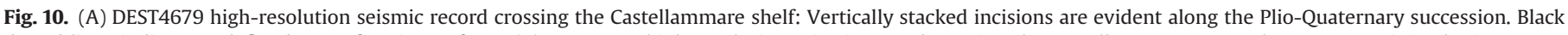

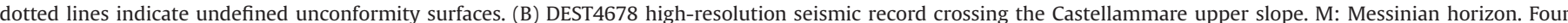

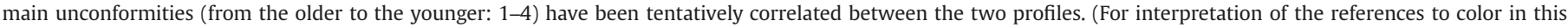
figure legend, the reader is referred to the web version of this article.)

Table 2

Comparison between the main canyon morphologic and sedimentary features in the two study areas.

\begin{tabular}{|c|c|c|}
\hline & Gulf of Palermo & Gulf of Castellammare \\
\hline Along-axis profile & Convex-upward & Concave-upward \\
\hline Headscarp shape & Amphitheater, cauliflower & Bird-foot \\
\hline Plain view path trajectory & Straight & Z-shape, sinuous to meandriform \\
\hline Headscarp position respect to the shelf margin & Shelf indenting, slope confined & Shelf indenting \\
\hline Type of evolution & Top-down, bottom-up & Top-down \\
\hline Sedimentary processes & Erosive sedimentary flows, slumps & Erosive sedimentary flows \\
\hline
\end{tabular}

is no evidence of mass wasting processes along them. Tributaries A and B merge with the Castellammare Canyon at depths of 900 and $1000 \mathrm{~m}$ respectively (Fig. 6). A third tributary, C, develops along the central sector of the upper slope, southwest the Castellammare Canyon (Fig. 6). Tributary C shows a less sinuous path (SI 1.16) and displays a U-shaped cross section and a flat bottom with flanks up to $25 \mathrm{~m}$ high. Downslope, it reduces its incision deeper than $900 \mathrm{~m}$, being scarcely recognizable in the MB bathymetric data for a section of almost $3 \mathrm{~km}$ ("channel infilling" in Fig. 7). At greater depths, Tributary $\mathrm{C}$ continues with a slightly sinuous course and merges with the Castellammare Canyon along its western flank at a depth of $1100 \mathrm{~m}$ (Fig. 6). Along its western sector the upper slope succession shows a higher slope gradient with intact slope deposits not affected by incisions (Fig. 6). In this area, the corresponding narrow shelf sector shows rough linear rocky outcrops up to the depth of $120 \mathrm{~m}$ and a rocky steep substrate on-land (Fig. 6). The slope region around the Cape San Vito is scoured by linear rills, incising a steep seafloor ranging $50 \mathrm{~m}$ to $900 \mathrm{~m}$ in depth. At the base of this slope sector, lobular debris flow deposits have been mapped along the basin at maximum depths of $940 \mathrm{~m}$ (Fig. 6).

4.2.1.2. San Vito Trough $(1100-2100 \mathrm{~m})$. At the depth of around $1100 \mathrm{~m}$, NE off the Cape San Vito, the Castellammare Canyon turns almost $90^{\circ}$ and enters the NE-SW trending structural depression of the San Vito Trough (Figs. 6 and 7). The canyon deeply incises the trough, displaying a convex-up meandering course (SI: 1.48), $30 \mathrm{~m}$ incised with up to $900 \mathrm{~m}$ wide $\mathrm{U}$ shaped cross sections (Fig. 8). The canyon becomes $\mathrm{V}$ shaped down-slope, producing steep walls up to $100 \mathrm{~m}$ high at the deepest and terminal sector of the trough, coinciding with a $100 \mathrm{~m}$ tall high at a depth of $1400 \mathrm{~m}$ (Fig. 9B). At greater depths, the Castellammare canyon displays a concave-up, straight to sinuous course, showing a flat-bottomed thalweg entrenched up to $60 \mathrm{~m}$ into the surrounding seafloor 


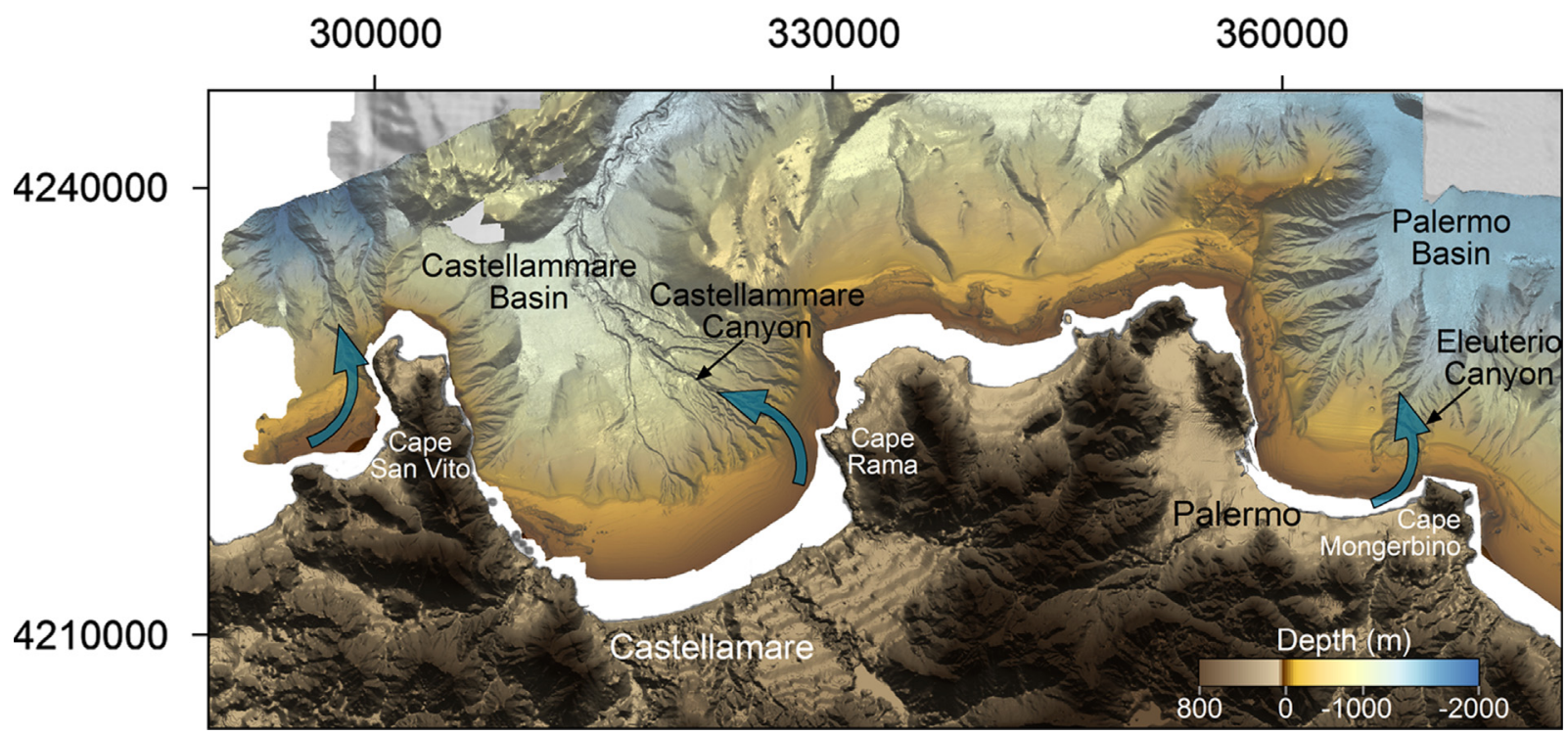

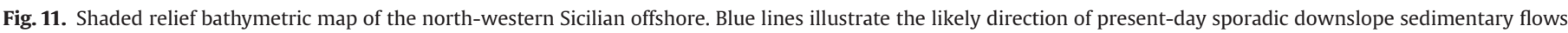

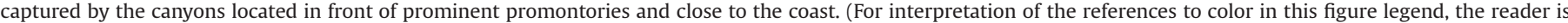
referred to the web version of this article.)

(Figs. 8 and 9). Our swath bathymetry data mapped the canyon up to the depth of $2100 \mathrm{~m}$.

\subsubsection{Seismostratigraphy}

Seismic reflection profiles from the Gulf of Castellammare reveal a dense network of buried valleys, scouring the PlioPleistocene sedimentary succession (Fig. 10). Across the margin, the Plio-Pleistocene succession, which is about $1 \mathrm{~s}$ thick, displays both a general clinoform depositional setting overlying the prograding slope, and a sub-horizontal and sub-parallel stratal pattern filling the intraslope Castellammare Basin. Plio-Pleistocene deposits overlay the tectonically deformed Meso-Cenozoic carbonate and terrigenous bedrock through an extensive unconformity imaged by seismic profiles as a prominent and well recognizable reflector interpreted here as the wide Messinian unconformity ("M" in Fig. 10b).

Seismic stratigraphy revealed the presence of five stacked sequences, up to a few hundred meters thick and bounded by basin-wide erosive surfaces (surfaces 1-4 in Fig. 10). Based on sequence stratigraphy interpretation and regional correlation (Agate et al., 2005; Catalano et al., 2011), the lowermost sequence has been correlated to the whitish hemipelagic chalks pertaining to the Trubi Formation (Early Pliocene), largely documented across the Tyrrhenian realm (Selli and Fabbri, 1971) and the Sicilian inland outcrops. The uppermost sequence has been correlated to the Late Pleistocene-Holocene last glacio-eustatic oscillation (Agate et al., 2005). Except for the Trubi Formation, the observed seismic units likely formed in a shelf to slope sedimentary environment, as documented by their seismo-stratigraphic features (Fig. 10): (a) their boundary unconformities show channelized erosional truncations, (b) stacked wedges of clinoforms and scattered channel levee complexes occur along the landward flank of the basin, and (c) lens-shaped, chaotic seismic facies units, interpretable as mass wasting deposits, are interbedded at different depths in the sedimentary succession. The uppermost sequence lies above a prominent unconformity (unconformity 4 in Fig. 10) corresponding to an extensive erosional truncation on the continental shelf (Fig. 10A) and to a disconformity downslope (Fig. 10b). Unconformity 4 is furrowed by a network of buried valleys connecting fluvial mouths along the coast to the main canyon headscarps along the shelf edge (Fig. 10A). Deposits overlaying unconformity 4 are interpreted to have accumulated along the shelf margin during the post-Marine Isotope Stage (MIS) 5 sea level fall (about $85 \mathrm{ka} \mathrm{BP}$ ) and the subsequent Last Glacial Maximum (LGM, about $18 \mathrm{ka}$ ) and along the inner shelf during the following sea level highstand phase (since about $6 \mathrm{ka}$ ) (Agate et al., 2005).

\section{Discussion}

Our data demonstrate that the Gulfs of Castellammare and Palermo display different submarine canyon landscapes (Table 2), despite them belonging to the same margin (South-Tyrrhenian border), the same inland geologic setting (Tertiary Sicilian Thrust Belt) and being exposed to similar oceanographic conditions. In the following sections we discuss bathymetric and seismic evidence related to the geological processes which govern these differences.

\subsection{Canyon forming processes in the Gulfs of Palermo and Castellammare}

\subsubsection{Palermo Canyons}

The Plio-Quaternary succession in the Gulf of Palermo developed on a steep Meso-Cenozoic substrate, downthrown by high angle normal faults (Figs. 1B and 2). The inshore outcropping of deformed, Upper Triassic, deep-water carbonates is consistent with this tectonic setting. The steep gradients of the slope and its convex-up geometry likely favoured the development of landslides along the lower slope, incising the Plio-Quaternary deposits and retrograding towards the shelf-margin. Once retrograding canyons breach the shelf-margin, the interaction with sedimentary fluxes along the shelf could have induced the creation of turbidity currents (Farre et al., 1983) and the maintenance of the axial incision along the canyons in concurrent top-down and bottomup scenarios. Older incisions along the foot of the slope were progressively buried by unconsolidated mass-wasting deposits resulting from the subsequent bottom-up erosion of the PlioQuaternary slope deposits. This evolution is also suggested by the resedimented deposits onlapping the eroded Plio-Quaternary succession in the basin (Fig. 5). The totality of the Palermo canyons terminates in the $1500 \mathrm{~m}$ deep sub-horizontal intraslope basin. 
The lack of active incisions for greater depths must be induced by the occurrence of the tectonically controlled barrier which confines the Palermo intra-slope Basin, hampering the action of sediment transport processes along deeper depths and favoring a depositional regime. Despite the presence of two main rivers crossing the Palermo plain (Fig. 3), a direct connection between river drainage and submarine canyons is evident for only the Oreto Canyon, where buried paleovalleys are recognized along the shelf region in front of the Oreto River, in proximity of the Oreto Canyon head (Lo Iacono et al., 2011). Mass wasting processes are actually widespread features in the Gulf of Palermo, with the Eleuterio Canyon shaped and widened by large landslides along its flanks, mapped in correspondence of tectonic features (Fig. 4).

Retrograding mechanisms could be controlled by active tectonics, as reported in the north-eastern Cretan margin (Strozyk et al., 2010). In this region, uplifting movements of the margin, contemporary with the subsidence of the Kamilonisi Basin, cause a progressive over-steepening of the lower slope and consequent headward erosion towards shallower and stable slope sectors (Strozyk et al., 2010). Tilting movements are likely to occur along the northern Sicilian margin, where coseismic uplift and subsidence effects have been reported over adjacent tectonic blocks (Sulli et al., 2012). On the Palermo margin, the $400 \mathrm{~m}$ deep slope sector exhibits a change in seafloor inclination (Fig. 2) and could likely represent the fulcrum of local tilting movements. In this area, as also observed in the Cretan margin (Strozyk et al., 2010), an over-critical slope exceeding $14^{\circ}$ would favor slope instabilities and mass movements evolving towards a less steep slope, as presently occurs at depths shallower than $400 \mathrm{~m}$ (Fig. 2).

\subsubsection{Castellammare Canyons}

Seismic data from the Castellammare Basin indicate that during the Late Pliocene-Pleistocene interval, downslope clastic sedimentation through submarine canyons contributed to the development of the shelf to slope system and nourished the basin until the present day. Turbidity currents related to river sediment discharges promoted the creation of a complex channel-levee system, developed with meandering channels, tributaries and gullies (Figs. 6, 7, and 10). Despite the variability and complexity of gullies and tributaries along the upper slope, vertical patterns of incisions observed in the seismic records (Fig. 10) suggest persistence through the Quaternary of canyon activity and sediment transport processes in the same shelf and slope sectors. Incisions along the outer shelf feed the canyon system converging to few but more incised features (Fig. 10A and B).

The buried valleys along the shelf suggest a direct connection with the coastal sedimentary transport system during glacial regressions and maxima. Valleys probably underwent a cyclic activity, successively filled and buried to then be re-incised, following rejuvenation by glacio-eustatic processes. In this scenario, the canyon system was most active during glacial phases, as observed in several canyon systems generated and controlled by turbidity processes (Hernandez-Molina et al., 2002; Baztan et al., 2005). The lack of extensive mass wasting features in the PlioQuaternary Castellammare sedimentary succession and in the present-day shelf-slope system (Fig. 10) is attributable to the geometry of the gentle inclined pre-Pliocene substrate above which the canyon system developed (Figs. 2 and 7).

In contrast to the steep Palermo Basin, the less steep prePliocene substrate of the Castellammare Basin promoted the creation of the thick Plio-Quaternary succession with low-angle horizons. This geologic setting contributed to generate low slope gradients and to the development of the sinuous to meandering submarine canyons, mainly controlled by top-down turbidity processes rather than by tectonic-controlled retrograding mechanisms. At a depth of $1100 \mathrm{~m}$, the Castellammare Canyon enters the San Vito Trough, which functions as a forced gateway for the Canyon along the non-confined intra-slope Castellammare Basin (Fig. 7). Along this sector the convex-up along axis profile suggests a tectonic uplift active during the Quaternary (Fig. 8), in accordance with previous observations (Antonioli et al., 2006; Sulli et al., 2012), which produced a $\mathrm{V}$ profile cross section and an incision of up to $94 \mathrm{~m}$ at a depth of $1300 \mathrm{~m}$ (Fig. 9A). Similar neotectonic related features have been observed in active convergent margins, such as the South Colombian and New Zealand-Hikurangi margins (Mountjoy et al., 2009; Ratzov et al., 2012). The occurrence in this sector of the partially filled tributary $C$ and of a likely terrace $20-25 \mathrm{~m}$ shallower than the actual canyon axis could also suggest canyon activity prior to the uplift (Fig. 9C).

\subsection{Canyon maintenance processes over the last glacial cycle}

Seismic and morphologic data suggest that most of the canyon systems observed on the north-western Sicilian margin were more active during the Quaternary glacial phases, when the sea level was around $120 \mathrm{~m}$ lower than present. Most of the canyons and gullies which are likely to have been controlled by top-down sedimentary fluxes, mainly linked to the river drainages and across shelf bottom currents, show their heads along the shelf margin and cut the coastal prograding wedges formed during the Last Glacial Maximum (LGM) (Figs. 3 and 6). A straight connection between actual canyon heads and fluvial sedimentary inputs is confirmed by the occurrence of several buried valleys along the Castellammare shelf, probably active during the lowstand sea level phases (Fig. 10A). We demonstrated that the Palermo canyons are controlled by bottom-up processes rather than by turbidity currents related to fluvial inputs. However, the shelf margin during the LGM was more subjected to strong hydrodynamics related to storms and to alongshore sediment transport, which could facilitate frequent sediment instabilities along the canyon heads.

MB bathymetry shows that the submarine canyons which actually display the deepest incisions, such as the Castellammare and Eleuterio Canyons, are located along the easternmost sector of each Gulf and in front of the most prominent promontories and capes of the study area (Fig. 11). In contrast, the rest of studied canyons generally display a smooth morphology and a reduced or absent axial incision. This observation suggests an enhanced activity of the easternmost submarine canyons in present time. It is likely that the combination between eastward storm-associated longshore drift, the narrowing of the continental shelf and the actual geometry of the coast (Figs. 3, 6, and 11) can favor canyons located very close to headlands in capturing currents and trapping sediment flows in their heads, which may promote downwelling processes and trigger sporadic downslope gravity flows (Xu et al., 2010). Similar processes have been largely documented in the western Mediterranean, for example in the Cap de Creus Canyon in the Gulf of Lion (Palanques et al., 2006; Ulses et al., 2008). In this area, during extreme winter storm events coinciding with major river floods, almost the totality of resuspended sediments along the shelf is transported through the Gulf to the head of the last canyon, in front of the Cape Creus, increasing down-canyon sediment fluxes and sediment transport events (Palanques et al., 2006; Martin et al., in press). Similar behaviors have been reported on the Portuguese margin, where canyons incising the shelf maintain their sedimentary activity during the present-day, acting as sediment traps (De Stigter et al., 2011).

Based on available data, we infer but cannot confirm that active erosive processes occur along the most incised Sicilian canyons. Downslope flows could remobilize fine sediments and reduce the highstand draping hemipelagic sedimentation along them, hence maintaining an incised morphology compared to the rest of the 
canyons, which actually represent just relict structures. However, direct oceanographic and sediment transport measurements are required to better highlight the actual activity and sedimentary processes of the canyons of north-western Sicily.

\section{Conclusions}

The application of Multibeam bathymetry and high resolution seismics revealed the presence of several submarine canyons in the Gulf of Palermo and the Gulf of Castellammare, along northwestern Sicily. Despite the two canyon systems belonging to the same continental margin and being located few kilometers apart, they display relevant differences in the morphologic characteristics and sedimentary processes. Retrograding mass movements breaching the Plio-Quaternary succession from the lower slope to the shelf are the main governing factors in shaping the steep Palermo canyons whereas downslope turbidity currents mainly related to fluvial sedimentary inputs during the glacial maxima controlled the evolution of the Castellammare canyons since the late Pliocene-early Pleistocene.

The different interplay between tectonics and sedimentary processes is recognized as the main geologic factor discriminating the evolution of the two canyon systems. The up to $14^{\circ}$ steep prePliocene substrate of the Palermo Basin favored the formation of linear and steep canyons controlled by retrograding mechanisms and the infilling of the intraslope basin by non-coherent mass transport deposits. The low gradient substrate of the Castellammare Basin promoted the creation of sinuous to meandering canyons, governed by downslope turbidity processes. Quaternary structural control of the margin is reflected in the studied canyon systems, with deep incisions and convex-up profiles enhanced by uplifting blocks in the Castellammare Basin and on-going inverse tectonics, and tilting movements regulating the retrogressive landslide dynamics in the Palermo Basin.

We conclude that present-day activity of Sicilian canyons is reduced. Canyons are isolated from the main sediment sources and they probably represent relict features, in contrast with their proved intense dynamics during the glacial phases. Nonetheless, the enhanced incision of the Castellammare and Eleuterio Canyons may suggest that the morphology of these features could be maintained in the present day by sporadic downslope gravity flows through alongshore currents deflected to the canyon heads by the narrowing shelf and the coastline topography.

\section{Acknowledgments}

We gratefully acknowledge the FP7 2011-2013 EU Marie Curie Action "Geo-Habit": GA29874 (Dr. Claudio Lo Iacono) and the Italian National Research Projects MaGIC (Marine Geological Hazard along the Italian Coast) funded by the Italian Civil Protection Department and CARG (Geological Maps of Italy) funded by the ISPRA-Italian Geological Survey. We also acknowledge the Grup de Recerca de la Generalitat de Catalunya B-CSI (2009 SGR 146). We are finally very grateful to the two reviewers, whose constructive criticism enabled us to significantly improve the quality of this paper.

\section{References}

Agate, M., Catalano, R., Infuso, S., Lucido, M., Mirabile, L., Sulli, A., 1993. Structura evolution of the northern Sicily continental margin during the Plio-Pleistocene. In: Max, M.D., Colantoni, P. (Eds.). Geological development of the SicilianTunisian Platform. UNESCO Reports in Marine Science 58, 25-30.

Agate, M., D'Argenio, A., Di Maio, D., Lo Iacono, C., Lucido, M., Mancuso, M. Scannavino, M., 1998. La dinamica sedimentaria dell'offshore della Sicilia Nord- occidentale durante il Tardo Quaternario. In: Catalano, R., Lo Cicero, G. (Eds.). La Sicilia occidentale. Guida alle escursioni del $79^{\circ}$ Congresso Nazionale della Società Geologica Italiana. pp. 157-167.

Agate, M., Beranzoli, L., Braun, T., Catalano, R., Favali, P., Frugoni, F., Pepe, F. Smriglio, G., Sulli, A., 2000. The 1998 offshore NW Sicily earthquakes in the tectonic framework of the southern border of the Tyrrhenian Sea. Mem. Soc Geol. Ital. 55, 103-114.

Agate, M., Mancuso, M., Lo Cicero, G., 2005. Late quaternary sedimentary evolution of the Castellammare Gulf (north-western Sicily offshore). Boll. Soc. Geol. Ital. $124,21-40$

Antonioli, F., Kershaw, S., Renda, P., Rust, D., Belluomini, G., Radtke, U., Silenzi, S. 2006. Altitude of the last interglacial highstand in Sicily (Italy) and its mplications for tectonic. Quat. Int. 145-146, 3-18.

Astraldi, M., Gasparini, G.P., Vetrano, A., Vignudelli, S., 2002. Hydrographic characteristics and interannual variability of water masses in the Mediterranean: a sensitivity test for long-term changes in the Mediterranean Sea. Deep Sea Res. I 49, 661-680.

Avellone, G., Barchi, M.R., Catalano, R., Gasparo Morticelli, M., Sulli, A., 2010 Interference between shallow and deep-seated structures in the Sicilian fold and thrust belt, Italy. J. Geol. Soc. 167, 109-126.

Bacini Sedimentari, 1980. Dati geologici preliminari sul bacino di Cefalù (Mar Tirreno). Ateneo Parmense. Acta Nat. 16, 3-18.

Baztan, J., Berne', S., Olivet, J.L., Rabineau, M., Aslanian, D., Gaudinb, M., Rehault, J.P., Canals, M., 2005. Axial incision: The key to understand submarine canyon evolution (in the western Gulf of Lion). Mar. Petrol. Geol. 22, 805-826.

Biscara, L., Hanquiez, V., Leynaud, D., Marieu, V., Mulder, T., Gallissaires, J.M., Crespin, J.P., Braccini, E., Garlan, T., 2012. Submarine slide initiation and evolution offshore Pointe Odden, Gabon: analysis from annual bathymetric data (2004-2009). Mar. Geol. 299-302, 43-50.

Canals, M., Casamor, J.L., Urgele’s, R., Lastras, G. Calafat, A.M., De Batist, M., Masson, D.G., Berne', S., Alonso, B., 2000. The Ebro Continental margin, Western Mediterranean Sea: interplay between canyon-channel systems and mast wasting processes. In: Proceedings of the 20th Annual Research Conference, GCSSEPM Foundation, Houston, TX.

Canals, M., Puig, P., Durrieu de Madron, X., Heussner, S., Palanques, A., Fabres, J., 2006. Flushing submarine canyons. Nature 444, 354-357, http://dx.doi.org 10.1038 /nature05271.

Catalano, R., D’Argenio, B., Montanari, L., Morlotti, E., Torelli, L., 1985. Marine geology of the NW Sicily offshore (Sardinia Channel) and its relationships with mainland structures. Boll. Soc. Geol. Ital. 104, 207-215.

Catalano, R., Franchino, A., Merlini, S., Sulli, A., 2000. Central western Sicily structural setting interpreted from seismic reflection profiles. Mem. Soc. Geol. Ital. 55, 5-16.

Catalano, R., et al., 2011. Castellammare del Golfo, note illustrative della carta geologica d'Italia alla scala 1:50.000. ISPRA: Servizio Geologico d'Italia. SystemCart, Roma, 239 pp.

Catalano R., Avellone G., Basilone L., Contino A., Agate M., Lo Iacono C., Di Maggio C. Sulli A., Gugliotta C., Gasparo Morticelli M., Albanese C., Caputo G., Di Maio D. Vattano M., Lo Cicero G., 2013. Sheet no. 595 Palermo. Note illustrative della carta geologica d'Italia alla scala 1:50.000. ISPRA: SGI. Regione Siciliana, Assessorato Territorio Ambiente. SystemCart, Roma. 224 pp.

Caruso, A., Cosentino, C., Pierre, C., Sulli, A., 2011. Sea-level changes during the last 41,000 years in the outer shelf of the southern Tyrrhenian Sea: evidence from benthic foraminifera and seismostratigraphic analysis. Quat. Int. 232 122-131.

Chiocci, F.L., Ridente, D., 2011. Regional-scale seafloor mapping and geohazard assessment. The experience from the Italian project MaGIC (Marine Geohazards along the Italian Coasts). Mar. Geophys. Res. 32, 13-23.

De Stigter, H.C., Jesus, C.C., Boer, W., de Jesus, Mendes, Richter, T.O., Costa, A., van Weering, T.C.E., 2011. Recent sediment transport and deposition in the LisbonSetubal and Cascais submarine canyons, Portuguese continental margin. Deep Sea Res. II: Top. Stud. Oceanogr. 58 (23-24), 2321-2344.

Del Ben, A., Guarneri, P., 2000. Neogene tranpression in the Cefalù Basin (Southern Tyrrhenian): comparison between land and marine data. Mem. Soc. Geol. Ital 55, 27-33.

Demirov, E., Pinardi, N., 2002. Simulation of the Mediterranean Sea circulation from 1979 to 1993: Part I. The interannual variability. J. Mar. Syst. 33-34, 23-50.

Epping, E., van der Zee, C., Soetaert, K., Helder, W., 2002. On the oxidation and burial of organic carbon in sediments of the Iberian margin and Nazare canyon (NE Atlantic). Prog. Oceanogr. 52 (2-4), 399-431.

Fabbri, A., Gallignani, P., Zitellini, N., 1981. Geological evolution of the periTyrrhenian sedimentary basins. In: Wezel, F. C. (Ed.). Sedimentary basins od Mediterranean margins. Tecnoprint, Bologna, pp. 101-126.

Farre, J.A., McGregor, B.A., Ryan, W.B.F., Robb, J.M., 1983. Breaching the shelfbreak: passage from youthful to mature phase in submarine canyon evolution. In: Stanley, D.J., Moore, G.T. (Eds.). The Shelfbreak: Critical Interface on Continental Margins. Society of Economic Paleontologists and Mineralogists, Tulsa, Oklahoma, pp. 25-39.

Ferranti, L., Antonioli, F., Anzidei, M., Monaco, C., Stocchi, P., 2010. The timescale and spatial extent of vertical tectonic motions in Italy: insights from relative sealevel changes studies. J. Virtual Explor. Electron. Ed. issn:1441-8142 issn:1441-814236 (paper 30).

Giunta, G., Luzio, D., Agosta, F., Calo, M., Di Trapani, F., Giorgianni, A., Oliveri, E. Orioli, S., Perniciaro, M., Vitale, M., Chiodi, M., Adelfio, G., 2009. An integrated approach to investigate the seismotectonics of northern Sicily and southern Tyrrhenian. Tectonophysics 476, 13-21. 
Harris, P.T., Whiteway, T., 2011. Global distribution of large submarine canyons: geomorphic differences between active and passive continental margins. Mar. Geol. 285, 69-86.

Hernandez-Molina, FJ, Somoza, L, Vàzquez, JT, Lobo, F, Fernandez-Puga, MC, Llave, E, Diaz del Rio, V, 2002. Quaternary stratigraphic stacking patterns on the continental shelves of the southern Iberian peninsula: their relationship with global climate and palaeoceanographic changes. Quat. Int. 921 (1), 5-23.

Huvenne, A.I., Tyler, P.A., Masson, D.G., Fisher, E.H., Hauton, C., Hühnerbach, V., Le Bas, T.P., Wolff, G.A., 2011. A picture on the wall: innovative mapping reveals cold-water coral refuge in Submarine Canyon Veerle. PLoS One 6 (12), http://dx. doi.org/10.1371/journal.pone.0028755.

Istituto Idrografico della Marina, 1982. Atlante delle correnti superficiali dei mari italiani, Genova.

Istituto Idrografico della Marina, 2002. Tidal Data Base, Genova.

Kastens, K., Mascle, J., Auroux, C., Bonatti, E., Broglia, C., Channell, J., Curzi, P., Emeis, K.C., Glacon, G., Asegawa, S., Hieke, W., Mascle, G., McCoy, F., McKenzie, J. Mendelson, J., Muller, C., Rehault, J.P., Robertson, A., Sartori, R., Sprovieri, R., Tori, M., 1988. ODP Leg 107 in the Tyrrhenian Sea: insights into passive margin and back-arc basin evolution. Geol. Soc. Am. Bull. 100, 1140-1156.

Lo Iacono, C., Sulli, A., Agate, M., Lo Presti, V., Pepe, F., Catalano, R., 2011. Submarine canyon morphologies in the Gulf of Palermo (Southern Tyrrhenian Sea) and possible implications for geo-hazard. Mar. Geophys. Res. 32, 127-138.

Marani, M.P., Gamberi, F., 2004. From seafloor to deep mantle: architecture of the Thyrrhenian backarc basin. Mem. Descr. Carta Geol. Ital. APAT Serv. Geol. Ital. LXIV, 109-126.

Martin, J., Durrieu de Madron, X., Puig, P., Bourrin, F., Palanques, A., Houpert, L Higueras, M., Sanchez-Vidal, A., Calafat, A.M., Canals, M., Heussner, S., 2013. Sediment transport along the Cap de Creus Canyon flank during a mild, wet winter, Biogeosciences 10, 2013, 3221-3239.

Mauz, B., Buccheri, G., Zoller, L., Greco, A., 1997. Middle to Upper Pleistocene morphostructural evolution of NW Sicily coast: thermoluminescience dating and paleontological-stratigrafical evaluations of littoral deposits. Paleogeogr. Paleoclimatol. Paleoecol. 128, 269-285.

Micallef, A., Mountjoy, J. J., Canals, M., Lastras, G., 2012. Deep-seated bedrock landslides and submarine canyon evolution in an active tectonic margin. In: Yamada, Y., Kawamura, K., Ikehara, K., et al. (Eds.). Submarine Mass Movements and their Consequences. Book Series: Advances in Natural and Technological Hazards Research 31, pp. 201-212 (http://dx.doi.org/10.1007/978-94-007-2162-3_18).

Mountjoy, J.J., Barnes, P.M., Pettinga, J.R., 2009. Morphostructure and evolution of submarine canyons across an active margin: Cook Strait sector of the Hikurang Margin, New Zealand. Mar. Geol. 260 (1-4), 45-68.

Palanques, A., Durrieu de Madron, X., Puig, P., Fabres, J., Guillàen, J., Calafat, A. Canals, M., Heussner, S., Bonnin, J., 2006. Suspended sediment fluxes and transport processes in the Gulf of Lions submarine canyons. The role of storms and dense water cascading. Mar. Geol. 234, 43-61.

Palanques, A., Puig, P., Durrieu de Madron, X., Sanchez-Vidal, A., Pasqual, C., Martín, J., Calafat, A., Heussner, S., Canals, M., 2012. Sediment transport to the deep canyons and open-slope of the western Gulf of Lions during the 2006 intense cascading and open-sea convection period. Prog. Oceanogr. 106, $1-15$.

Pepe, F., Sulli, A., Agate, M., Di Maio, D., Kok, A., Lo Iacono, C., Catalano, R., 2003. Plio-Pleistocene geological evolution of the northern Sicily continental margin (southern Tyrrhenian Sea): new insights from high resolution, multi-electrode sparker profiles. Geol. Mar. Lett. 23, 53-63.

Pepe, F., Sulli, A., Bertotti, G., Catalano, R., 2005. Structural highs formation and their relationships to sedimentary basins in the north Sicily continental margin (southern Tyrrhenian Sea): implication for the Drepano thrust front. Tectonophysics 409, 1-18.

Piper, D.J.W., Savoye, B., 1993. Processes of late Quaternary turbidity current flow and deposition on the Var deep-sea fan, north-west Mediterranean Sea. Sedimentology 40, 557-582.

Pratson, L.F., Coakley, B.J., 1996. A model for the headward erosion of submarine canyons induced by downslope-eroding sediment flows. Geol. Soc. Am. Bull. 108 (2), 225-234.

Ratzov, G., Sosson, M., Collot, J.Y., Migeon, S., 2012. Late Quaternary geomorphologic evolution of submarine canyons as a marker of active deformation on convergent margins: the example of the South Colombian margin. Mar. Geol. 315-318, 77-97.

Scarascia, S., Lozej, A., Cassinis, R., 1994. Crustal structures of the Ligurian, Tyrrhenian and Ionian Sea and adjacent onshores areas interpreted from wide-angleseismic profile. Boll. Geof. Teor. Appl. 36, 5-19.

Selli, R., 1970. Cenni morfologici generali sul Mar Tirreno. G. Geol. 37, 5-24.

Selli, R., Fabbri, A., 1971. Tyrrhenian: a Pliocene deep sea. Accad. Naz. Lincei Rend. Cl. Sci. Fis. Mat. Nat. S 8 (50), 580-592.

Shepard, F.P., 1981. Submarine canyons: multiple causes and long-time persistence. AAPG Bull. 65, 1062-1077.

Strozyk, F., Strasser, M., Krastel, S., Meyer, M., Huhn, K., 2010. Reconstruction of retreating mass wasting in response to progressive slope steepening of the northeastern Cretan margin, eastern Mediterranean. Mar. Geol. 271, 44-54.

Sulli, A., Lo Presti, V., Gasparo Morticelli, M., Antonioli, F., 2012. Vertical movements in NE Sicily and its offshore: outcome of tectonic uplift during the last $125 \mathrm{ky}$. Quat. Int., 1-15.

Twichell, D.C., Roberts, D.G., 1982. Morphology, distribution and development of submarine canyons on the United States Atlantic continental slope between Hudson and Baltimore Canyon. Geology 10, 408-412.

Ulses, C., Estournel, C., Durrieru de Madron, X., Palnques, A., 2008. Suspended sediment transport in the Gulf of Lions (NW Mediterranean): impact of extreme storms and floods. Cont. Shelf Res. 28, 2048-2070.

Wynn, R.B., Cronin, B.T., Peakall, J., 2007. Sinuous deep-water channels: genesis, geometry and architecture. Mar. Petrol. Geol. 24, 341-387.

Xu, J.P., Swarzenski, P.W., Noble, M., Li, A.C., 2010. Event-driven sediment flux in Hueneme and Mugu submarine canyons, southern California. Mar. Geol. 269, $74-88$. 